\title{
EFEKTIVITAS BIOKOAGULAN Vicia faba DALAM MEMPERBAIKI LIMBAH CAIR PULP DAN KERTAS
}

\author{
Miranti Ariyani ${ }^{1)}$, Saefudin $^{2)}$, Tina Safaria Nilawati ${ }^{2)}$ \\ ${ }^{1)}$ Program Studi Pendidikan Biologi STKIP Garut \\ ${ }^{2)}$ Jurusan Pendidikan Biologi Fakultas Pendidikan Matematika dan Ilmu Pengetahuan Alam \\ Universitas Pendidikan Indonesia, Bandung \\ e-mail: miranti.ariyani@yahoo.com; saefudin@yahoo.com; tsnilawati@yahoo.com
}

\begin{abstract}
ABSTRAK
Telah dilakukan penelitian mengenai efektivitas kacang babi Vicia faba sebagai biokoagulan dalam memperbaiki sifat fisik dan kimiawi limbah cair industri pulp dan kertas. Penelitian ini bertujuan untuk mengetahui kemampuan dan konsentrasi Vicia faba yang optimum dalam memperbaiki sifat fisik kimiawi limbah cair industri pulp dan kertas. Sifat fisik dan kimia yang diteliti mencakup turbiditas, total padatan tersuspensi (TSS) limbah, kandungan kesadahan dan Chemical Oxygen Demand (COD) limbah. Rancangan penelitian yang digunakan dalam penelitian ini adalah Rancangan Acak Lengkap (RAL), dengan lima taraf konsentrasi yaitu $0,02 \% ; 0,04 \% ; 0,06 \% ; 0,08 \%$ dan $0,1 \%(\mathrm{v} / \mathrm{v})$ masing-masing dengan lima kali pengulangan. Hasil penelitian menunjukkan bahwa konsentrasi suspensi Vicia faba sebanyak 0,1\% mampu menurunkan turbiditas limbah hingga mencapai 98,5\% dan TSS limbah hingga mencapai 74,8\%. Untuk parameter kimiawi, pada konsentrasi tersebut mampu menurunkan kesadahan limbah hingga 41,6\%, dan kandungan COD limbah mencapai 60,6\%.
\end{abstract}

Kata kunci : Vicia faba, biokoagulan, limbah cair industri pulp dan kertas

\section{EFECTIVITY OF Vicia faba AS BIOCOAGULANT FOR PULP AND PAPER WASTE WATER}

\begin{abstract}
The Study about Efectivity of broad bean (Vicia faba) as a biocoagulant for pulp and paper mill waste water were conducted. Coagulation-flocculation is an important process in wastewater treatment that are used to remove colloid and suspended particles. The objective of this research was to determine the ability and the optimum concentration of Vicia faba. The observed parameters during this research were Turbidity, Total Suspended Solid, Total Hardness and Chemical Oxygen Demand. The study was conducted using Randomize Complete Design with five replications and five level concentrations $(0,02 \% ; 0,04 \% ; 0,06 \% ; 0,08 \% ; 0,1 \%)$. The data show that the optimum concentration of Vicia faba was around $0,1 \%$. Vicia faba at concentration $0,1 \%$ effectively removes turbidity over $98,5 \%, 74,8 \%$, for Total Suspended Solid, 60,6\% of Chemical Oxygen Demand and 41,6\% for total hardness.
\end{abstract}

Keywords: Vicia faba, biocoagulant, pulp and paper mill waste water

\section{PENDAHULUAN}

Industri pengolahan hasil hutan, salah satunya industri pulp dan kertas, merupakan salah satu penyumbang limbah cair yang cukup berbahaya bagi lingkungan. Peningkatan produksi pada industri tersebut diikuti dengan adanya air buangan dengan kadar polutan yang cukup tinggi (Dwinarjati,
1995). Menurut Singh (1976), air buangan pada industri pulp dan kertas terutama dihasilkan dari proses pulping, bleaching dan papermaking. Polutan dalam air buangan tersebut adalah senyawa organik koloid, serat hemiselulosa, zat pengurai serat, perekat, kandungan selulosa, serat sintetik, dan bahan seluler lainnya. Bahan-bahan polutan di atas menyebabkan tingginya tingkat kekeruhan air 
limbah dan tingginya kadar Chemical Oxygen Demand (COD) (Setyorini, 2002; Wardhana, 2004).

Proses koagulasi-flokulasi merupakan salah satu tahapan pengolahan limbah secara fisik-kimia. Tahap ini memegang peranan penting untuk menghilangkan partikel-partikel terlarut dan tersuspensi. Secara umum, proses koagulasi-flokulasi merupakan proses pengumpulan partikelpartikel halus yang tidak dapat diendapkan secara gravitasi menjadi partikel yang lebih besar (Waluyo, 2005). Pada umumnya bahan kimia yang digunakan pada proses koagulasiflokulasi pada pengolahan limbah cair adalah Polyalumuniumchloride (PAC). PAC atau yang lebih dikenal dengan nama alum merupakan salah satu bahan kimia yang digunakan sebagai koagulan dalam pengolahan limbah industri pulp dan kertas. Penggunaan alum efektif dalam pengolahan limbah tetapi dapat menimbulkan kerugian diantaranya menambah residu terlarut dan kandungan logam pada lumpur hasil pengendapan (Ghebremichael, 2004). Residu dari alum dapat membahayakan kesehatan, salah satu diantaranya adalah penyakit alzheimers (Liew et al., 2004; Nkhata, 2001).

Penggunaan beberapa bahan kimia dalam pengolahan air limbah terbukti menimbulkan dampak negatif baik bagi lingkungan maupun kesehatan masyarakat (Liew et al., 2004; Ghebremichael, 2004). Hal ini menyebabkan dibutuhkannya suatu koagulan alternatif yang keberadaannya dapat menggantikan fungsi dari PAC yang biasa digunakan dalam pengolahan limbah industri khususnya limbah cair industri pulp dan kertas.

Beberapa bahan alami yang telah diketahui dapat berperan sebagai koagulan alternatif diantaranya Moringa oleifera (Babu \& Chauduri, 2005; Sutherland et al., 1990; Ndabigengesere \& Narasiah, 1998), Strychnos potatorum (Cohen \& Hannah, 1971) dan kacang-kacangan seperti Vigna unguiculata (Liew et al., 2004). Beberapa penelitian menunjukkan bahwa koagulan alami seperti Moringa oleifera dan beberapa tumbuhan lainnya terbukti lebih efektif dalam pengolahan limbah dibandingkan dengan penggunaan PAC baik dalam hal turbiditas dan kandungan kimia dari limbah yang dihasilkan. Penggunaan Moringa oleifera sebagai koagulan alami pada pengolahan limbah domestik secara signifikan dapat menurunkan kadar materi tersuspensi dan beberapa jenis logam berat dibandingkan limbah yang diolah dengan menggunakan PAC (Ndabigengesere \& Narasiah, 1998). Penggunaan tumbuhan ini dalam pengolahan limbah domestik juga dapat menurunkan turbiditas limbah hingga 98,94\% (Folkard \& Sutherland, 2001). Penggunaan Vigna unguiculata sebagai koagulan alami dalam pengolahan limbah dapat menurunkan turbiditas hingga lebih dari $80 \%$. Penggunaan koagulan alami dalam pengolahan limbah terbukti dapat menghemat biaya, mengurangi endapan yang dihasilkan, dan tentu saja mudah diuraikan (biodegradable) (Ghebremichael, 2004).

Dari sekian banyak tumbuhan yang dimanfaatkan sebagai koagulan alami, Vicia faba memiliki daya koagulan yang tinggi, hanya saja pemanfaatannya belum dilakukan secara optimal dalam pengolahan limbah di Indonesia. Vicia faba dikenal memiliki kandungan protein yang cukup tinggi yaitu berkisar $20-25 \%$ dan beragam jenis asam amino dengan kadar yang cukup tinggi, dalam 100 gram Vicia faba terkandung 26,2 gram protein (Duke, 1983). Protein yang terkandung dalam Vicia faba inilah yang nantinya diharapkan dapat menggantikan fungsi dari PAC. Protein yang merupakan salah satu penyusun dari Vicia faba dan beberapa tanaman famili Leguminosae lainnya dapat berfungsi sebagai polielektrolit kationik alami dan menunjukkan hasil koagulasi positif (Babu \& Chauduri, 2005; Sutherland et al., 1990).

Penggunaan konsentrasi Vicia faba yang tepat sangat penting dalam keefektivitasannya memperbaiki sifat fisik dan kimiawi limbah. Konsentrasi Vicia faba yang terlalu minim atau berlebih, sedikit banyak akan mempengaruhi sifat fisik dan kimiawi limbah yang dihasilkan. Berdasarkan latar belakang tersebut maka diperlukan penelitian untuk mengetahui kemampuan dan konsentrasi Vicia faba yang optimum sebagai koagulan dalam pengolahan limbah cair industri pulp dan kertas sehingga dapat memenuhi baku mutu limbah cair. 


\section{BAHAN DAN METODE}

Penelitian dan analisis fisik limbah dilakukan di lab. Fisiologi Jurusan Pendidikan Biologi FPMIPA UPI. Analisis kimia limbah dilakukan di lab. Kimia analitik UNPAD. Materi utama yang digunakan di dalam penelitian ini adalah kacang babi Vicia faba yang diperoleh dari Pegunungan Dieng, Kecamatan Wonosobo, Jawa Tengah serta limbah cair industri pulp dan kertas dari proses pembuatan kertas halus. Penelitian dilakukan dengan Rancangan Penelitian Acak Lengkap terdiri atas 1 kontrol dan 5 perlakuan yang masing-masing terdiri atas 5 kali pengulangan yang ditentukan berdasarkan penelitian pendahuluan.

\section{Cara Kerja \\ Pembuatan Suspensi Kacang babi Vicia faba}

Kacang babi yang digunakan dalam pembuatan suspensi adalah kacang babi tua kering yang berwarna cokelat. Kacang babi kemudian direndam dengan air dingin selama 12 jam kemudian dikupas kulitnya dan dikeringkan. Kacang babi yang telah kering kemudian dihaluskan dengan menggunakan blender, diayak, dan disaring hingga didapatkan serbuk halus. Serbuk halus kacang babi dibuat suspensi $2 \%(\mathrm{~b} / \mathrm{v})$ dengan menggenapkan $2 \mathrm{~g}$ serbuk dengan aquades hingga volumenya $100 \mathrm{ml}$. Serbuk yang telah dicampur dengan aquades, akan melarutkan proteinnya yang yang dapat berperan sebagai polielektrolit kationik alami (Sutherland et al., 1990). Pembuatan suspensi kacang babi sesuai dengan konsentrasi yang diinginkan dilakukan dengan cara pengenceran dengan rumus $\mathrm{V}_{1} \times \mathrm{M}_{1}=\mathrm{V}_{2} \mathrm{x} \mathrm{M}_{2}$.

\section{Pelaksanaan Jar Test}

Sampel air limbah terlebih dahulu diukur $\mathrm{pH}$, turbiditas, COD, kesadahan, dan temperaturnya. Sampel air limbah kemudian diaduk dengan menggunakan stirer hingga homogen. Suspensi Vicia faba dengan konsentrasi yang diinginkan selanjutnya dimasukkan ke dalam beaker glass dan digenapkan dengan sampel limbah hingga volumenya $500 \mathrm{ml}$. Sampel limbah yang telah ditambahkan suspensi Vicia faba kemudian diatur tingkat keasamannya hingga mencapai $\mathrm{pH} 3$ yang diperoleh dari tahap pra penelitian dengan menambahkan $\mathrm{H}_{2} \mathrm{SO}_{4} 2 \mathrm{M}$ dan $\mathrm{NaOH}$
10\%. Sampel limbah diaduk dengan kecepatan tinggi $156 \mathrm{rpm}$ selama 10 menit dan kecepatan rendah $40 \mathrm{rpm}$ selama 15 menit. Setelah tahap jar tes selesai sampel kemudian didiamkan selama 120 menit $( \pm 2$ jam),

\section{Variabel Pengamatan}

Kandungan turbiditas diukur dengan menggunakan Portabel Turbidity Meter.Total Padatan Tersuspensi (TSS) diukur dengan menggunakan metode pengeringan pada suhu $103-105^{\circ} \mathrm{C}$ (APHA, AWWA dan WCPF, 1985; Hauser, 2002). Kandungan Chemical Oxygen Demand (COD) limbah diukur dengan menggunakan metode reflux terbuka (APHA, AWWA dan WCPF, 1985). Kandungan kesadahan limbah diukur dengan menggunakan metode titrasi dengan Etilen Diamine Tetra Asetat (EDTA) (APHA, AWWA dan WCPF, 1985). Pengukuran $\mathrm{pH}$ limbah dilakukan dengan $\mathrm{pH}$ meter (APHA, AWWA dan WCPF, 1985).

\section{Analisis Data}

Data-data turbiditas (NTU), TSS $(\mathrm{mg} / \mathrm{l})$, kesadahan $(\mathrm{CaO} / \mathrm{l})$ dan $\mathrm{COD}(\mathrm{mg} / \mathrm{l})$ yang diperoleh dihitung efektivitasnya dengan menggunakan rumus efektivitas (Sofiany, 1999). Nilai efektivitas yang diperoleh diuji dengan menggunakan analisis statistik Analisis Variansi (ANAVA) dengan taraf signifikansi $0,05(\alpha=0,05)$, dan dilanjutkan dengan uji Tukey pada taraf signifikansi 0,05. Data diolah dengan menggunakan perangkat Software SPSS Versi 12.0 .

\section{HASIL DAN PEMBAHASAN}

\section{Turbiditas Limbah}

Berdasarkan Tabel 1 dapat dilihat bahwa efektivitas penurunan turbiditas limbah yang dihasilkan semakin baik seiring dengan meningkatnya konsentrasi Vicia faba yang diberikan.

Efektivitas penurunan turbiditas terendah terdapat pada pemberian konsentrasi Vicia faba sebanyak $0,02 \%$ yaitu sebesar $92,7 \%$ sedangkan efektivitas penurunan turbiditas tertinggi terjadi pada limbah dengan penambahan konsentrasi Vicia faba sebanyak 0,1\% yaitu sebesar 98,5\%. Berdasarkan perhitungan statistika dengan 
menggunakan analisis statistik Kruskal wallis pada taraf signifikansi 5\% untuk efektivitas turbiditas, diperoleh nilai sig. $>0,05$. Nilai ini menunjukkan bahwa terdapat perbedaan median efektivitas penurunan turbiditas yang dihasilkan akibat pemberian suspensi Vicia faba dengan konsentrasi yang berbeda.

Tabel 1. Data nilai akhir turbiditas limbah dan efektivitas penurunan turbiditas setelah proses koagulasi-flokulasi oleh suspensi Vicia faba dengan konsentrasi yang berbeda-beda

\begin{tabular}{|c|c|c|c|c|}
\hline \multirow[b]{2}{*}{ No } & \multirow[b]{2}{*}{$\begin{array}{c}\text { Konsentrasi } \\
\text { Vicia faba }(\%)\end{array}$} & \multicolumn{2}{|c|}{ Turbiditas (NTU) } & \multirow{2}{*}{$\begin{array}{c}\text { Efektivitas } \\
\text { penurunan } \\
(\%)\end{array}$} \\
\hline & & $\begin{array}{c}\text { Sebelum } \\
\text { Perlakuan }\end{array}$ & $\begin{array}{c}\text { Sesudah } \\
\text { Perlakuan }\end{array}$ & \\
\hline 1 & 0 & 372,3 & 139,4 & 62,6 \\
\hline 2 & 0,02 & 295,3 & 21,6 & 92,7 \\
\hline 3 & 0,04 & 233,1 & 9,7 & 95,8 \\
\hline 4 & 0,06 & 250,9 & 9,9 & 96,1 \\
\hline 5 & 0,08 & 253,8 & 8,3 & 96,7 \\
\hline 6 & 0,1 & 264,7 & 3,9 & 98,5 \\
\hline
\end{tabular}

Tabel 2. Data kandungan akhir TSS limbah dan efektivitas penurunan TSS setelah proses koagulasi-flokulasi oleh suspensi Vicia faba dengan konsentrasi yang berbedabeda

\begin{tabular}{|c|c|c|c|c|}
\hline \multirow[b]{2}{*}{ No } & \multirow{2}{*}{$\begin{array}{l}\text { Konsentrasi } \\
\text { Vicia faba }(\%)\end{array}$} & \multicolumn{2}{|c|}{ TSS (mg/l) } & \multirow{2}{*}{$\begin{array}{l}\text { Efektivitas } \\
\text { penurunan } \\
(\%)\end{array}$} \\
\hline & & $\begin{array}{l}\text { Sebelum } \\
\text { Perlakuan }\end{array}$ & $\begin{array}{l}\text { Sesudah } \\
\text { Perlakuan }\end{array}$ & \\
\hline 1 & 0 & 231,2 & 231,2 & 0 \\
\hline 2 & 0,02 & 231,2 & 130,6 & 43,5 \\
\hline 3 & 0,04 & 231,2 & 100,2 & 56,7 \\
\hline 4 & 0,06 & 231,2 & 98,2 & 57,5 \\
\hline 5 & 0,08 & 231,2 & 87,6 & 62,1 \\
\hline 6 & 0,1 & 231,2 & 58,2 & 74,8 \\
\hline
\end{tabular}

Tabel 1 memperlihatkan efektivitas penurunan turbiditas limbah meningkat seiring dengan meningkatnya konsentrasi Vicia faba yang diberikan, hal ini menunjukkan bahwa semakin tinggi konsentrasi polielektrolit yang diberikan, efektivitas penurunan turbiditas yang dihasilkan semakin baik karena penambahan konsentrasi elektrolit akan mengakibatkan berkurangnya kestabilan koloid dan akan mengurangi gaya tolak menolak antar partikel sehingga menunjang proses pengendapan (Olphen, 1977). Limbah cair industri pulp dan kertas sebagian besar terdiri atas bahan organik. Limbah yang sebagian besar mengandung bahan organik memiliki koloid dengan muatan negatif. Limbah ini sangat sulit untuk terkoagulasi sehingga dosis koagulan yang dibutuhkan dalam hal ini gugus $\mathrm{NH}_{3}{ }^{+}$yang terdapat pada protein akan semakin banyak untuk mendukung terjadinya ikatan antara protein kacang babi dengan koloid (Amirtharajah \& O'Melia, 1990; Cohen \& Hannah, 1971). Efektivitas penurunan turbiditas terendah dihasilkan pada penambahan suspensi Vicia faba sebanyak $0,02 \%$, hal ini terjadi karena penambahan polielektrolit dengan konsentrasi rendah akan menyebabkan proses koagulasi diperlambat karena terdapat gaya tolak menolak yang sangat kuat yang menyebabkan koloid tetap stabil (Olphen, 1977).

\section{Total Padatan Tersuspensi}

Tabel 2 menunjukkan bahwa efektivitas penurunan TSS mengalami peningkatan seiring dengan meningkatnya konsentrasi suspensi Vicia faba yang diberikan. Efektivitas penurunan TSS tertinggi terdapat pada limbah dengan penambahan suspensi Vicia faba sebanyak $0,1 \%$ sebesar $74,8 \%$, sedangkan efektivitas 
penurunan TSS terendah terdapat pada penambahan suspensi Vicia faba sebanyak $0,02 \%$ yaitu $43,5 \%$.

Berdasarkan perhitungan statistika dengan menggunakan uji ANAVA pada taraf signifikansi 5\%, diperoleh nilai sig. $>0,05$. Nilai ini menunjukkan adanya perbedaan efektivitas penurunan TSS karena pemberian suspensi Vicia faba dengan konsentrasi yang berbeda. Hasil penelitian menunjukkan bahwa pada rentang konsentrasi yang diberikan, efektivitas penurunan TSS tertinggi diperoleh pada konsentrasi tertinggi yaitu $0,1 \%$, hal ini terjadi karena efek dari polielektrolit terhadap kestabilan koloid tergantung pada konsentrasinya. Penambahan elektrolit dengan konsentrasi yang tinggi, akan menghilangkan gaya tolak menolak antar koloid sehingga menyebabkan panggabungan partikel maksimum (Olphen, 1977). Selain $\mathrm{pH}$ dan dosis koagulan, salah satu faktor yang menyebabkan berkurangnya jumlah materi tersuspensi dalam limbah adalah proses pengadukan, proses ini menyebabkan partikel terdestabilisasi yang mencakup pengurangan gaya tolak menolak antar partikel dan pada akhirnya menimbulkan kontak dan agregasi partikel (Culp et al., 1986; Cohen \& Hannah, 1971).

\section{Kesadahan (Total hardness)}

Tabel 3 menunjukkan bahwa efektivitas Vicia faba dalam menurunkan angka kesadahan mengalami peningkatan seiring dengan meningkatnya konsentrasi suspensi Vicia faba yang diberikan. Efektivitas penurunan kesadahan tertinggi dihasilkan pada limbah dengan penambahan suspensi Vicia faba sebanyak $0,1 \%$ sebesar $41,6 \%$, sedangkan efektivitas penurunan kesadahan terendah dihasilkan pada penambahan suspensi Vicia faba sebanyak $0,02 \%$ yaitu $19,9 \%$.

Tabel 3. Data kandungan akhir kesadahan limbah dan efektivitas penurunan kesadahan setelah proses koagulasi-flokulasi oleh suspensi Vicia faba dengan konsentrasi yang berbeda-beda

\begin{tabular}{|c|c|c|c|c|}
\hline \multirow{2}{*}{ No } & \multirow{2}{*}{$\begin{array}{c}\text { Konsentrasi } \\
\text { Vicia faba }(\%)\end{array}$} & Sebelum Perlakuan & Sesudah Perlakuan & $\begin{array}{c}\text { Efektivitas } \\
\text { penurunan } \\
(\%)\end{array}$ \\
\hline 1 & 0 & 128,7 & 128,7 & 0 \\
\hline 2 & 0,02 & 128,7 & 103,1 & 19,9 \\
\hline 3 & 0,06 & 128,7 & 101,8 & 20,9 \\
\hline 4 & 0,1 & 128,7 & 75,2 & 41,6 \\
\hline
\end{tabular}

Tabel 4. Data kandungan akhir Chemical Oxygen Demand (COD) limbah dan efektivitas penurunan COD setelah proses koagulasi-flokulasi oleh suspensi Vicia faba dengan konsentrasi yang berbeda-beda

\begin{tabular}{|l|l|l|c|l|}
\hline \multirow{2}{*}{ No } & \multirow{2}{*}{$\begin{array}{c}\text { Konsentrasi } \\
\text { Vicia faba (\%) }\end{array}$} & \multicolumn{2}{|c|}{ COD (mg/l) } & Efektivitas \\
\cline { 3 - 5 } & Perlakuan & $\begin{array}{c}\text { Sesudah } \\
\text { Perlakuan }\end{array}$ & \\
\hline 1 & 0 & 298,2 & 298,2 & 0 \\
\hline 2 & 0,02 & 298,2 & 163,8 & 45,1 \\
\hline 3 & 0,06 & 298,2 & 125,5 & 57,9 \\
\hline 4 & 0,1 & 298,2 & 117,5 & 60,6 \\
\hline
\end{tabular}

Berdasarkan perhitungan statistika dengan menggunakan uji ANAVA pada taraf signifikansi $5 \%$, diperoleh nilai sig.> 0,05 . Nilai ini menunjukkan adanya perbedaan efektivitas penurunan kesadahan karena pemberian suspensi Vicia faba dengan konsentrasi yang berbeda. Timbulnya perbedaan hasil efektivitas penurunan kesadahan pada beberapa konsentrasi disebabkan karena dengan pertambahan rantai peptida, kemampuan senyawa tersebut untuk mengikat ion logam yang sama juga bertambah cepat (Darmono, 1995). Hal ini menunjukkan bahwa semakin tinggi konsentrasi polielektrolit yang diberikan, efektivitas penurunan kesadahan yang 
dihasilkan semakin baik. Hal ini terjadi karena hampir semua ion logam selalu berinteraksi dengan kompleks protein secara cepat karena protein memiliki gugus amina dan karboksil yang dapat mengikat logam (Darmono, 1995). Interaksi antara logam dengan protein dapat berupa ikatan ionik, kovalen polar dan kompleks. Dalam ikatan ini, protein berfungsi sebagai sumber gugus fungsi seperti karboksil, fosfat, hidroksil, amina, sulfur dan sulfida dalam mengikat ion logam (Wang \& Chen, 2006). Seperti diketahui bahwa semakin tinggi muatan kation dari logam semakin kuat ikatannya dengan protein daripada kation logam yang muatannya lebih rendah, sehingga ikatan tersebut lebih stabil dan konstan (Darmono, 1995). Kalsium merupakan logam yang dapat berikatan kuat dengan gugus yang terdapat pada protein (Poedjiadi, 1994).

\section{Chemical Oxygen Demand (COD)}

Tabel 4 menunjukkan bahwa efektivitas penurunan COD mengalami peningkatan seiring dengan meningkatnya konsentrasi suspensi Vicia faba yang diberikan. Efektivitas penurunan COD tertinggi dihasilkan pada limbah dengan penambahan suspensi Vicia faba sebesar $0,1 \%$ yaitu $60,6 \%$, sedangkan efektivitas penurunan COD terendah dihasilkan pada penambahan suspensi Vicia faba sebanyak $0,02 \%$ sebesar $45,1 \%$.

Berdasarkan perhitungan statistika dengan menggunakan uji ANAVA pada taraf signifikansi 5\% diperoleh nilai sig. $>0,05$. Nilai ini menunjukkan adanya perbedaan efektivitas penurunan COD karena pemberian suspensi Vicia faba dengan konsentrasi yang berbeda. Hasil penelitian menunjukkan bahwa efektivitas penurunan COD terbesar diperoleh pada pemberian Vicia faba pada konsentrasi $0,1 \%$. Diduga penurunan COD ini disebabkan oleh partikel koloid biokogulan yang mampu berikatan dengan pencemar organik yang berasal dari limbah sehingga menyebabkan gaya tolak menolak berkurang, dan menunjang pembentukan dan pengendapan flok. Berkurangnya partikel yang terdapat pada limbah, menyebabkan jumlah oksigen yang digunakan untuk mendegradasi partikel secara kimia menjadi berkurang pula (Hidayat, 1999). Rendahnya penurunan kandungan COD pada penambahan suspensi Vicia faba sebanyak
0,02\%, diakibatkan karena hanya sedikit rantai peptida dari protein yang tersedia sedangkan partikel koloid yang terdapat pada limbah cukup banyak, dengan kata lain jumlah rantai peptida yang tersedia tidak sebanding dengan jumlah partikel koloid. Hal ini akan mengakibatkan proses penjembatanan oleh rantai peptida terbatas bahkan gagal terjadi (Cohen \& Hannah, 1971).

\section{KESIMPULAN}

Hasil penelitian menunjukkan bahwa Vicia faba mampu berperan sebagai biokoagulan sehingga dapat memperbaiki sifat fisik dan kimiawi limbah cair industri pulp dan kertas. Pada rentang konsentrasi yang diberikan semakin banyak konsentrasi suspensi Vicia faba yang digunakan semakin besar efektivitas sifat fisik dan kimiawi limbah cair industri pulp dan kertas yang dihasilkan.Pada pemberian suspensi Vicia faba sebanyak $0,1 \%$, efektivitas dalam perbaikan kualitas sifat fisik dan kimiawi limbah cair industri pulp dan kertas yang mencakup turbiditas, total padatan tersuspensi (TSS), kesadahan dan chemical oxygen demand (COD) mencapai nilai yang optimum. Pada konsentrasi tersebut, efektivitas penurunan turbiditas yang dihasilkan mencapai 98,5\%, sedangkan efektivitas penurunan TSS yang dihasilkan mencapai $74,8 \%$. Untuk parameter kimiawi, pada konsentrasi tersebut efektivitas penurunan kesadahan limbah yang dihasilkan sebesar 41,6\%, sedangkan efektivitas penurunan COD limbah yang dihasilkan mencapai $60,6 \%$.

\section{DAFTAR PUSTAKA}

Amirtharajah, A., and C.R. O' Melia .1990. Coagulation Processes; Destabilisation, Mixing and Flocculation. In : Water Quality and Treatment (a Handbook of Community Water Supplies). Edisi ke 4. Mc Graw Hill. Inc, New York. 
APHA, AWWA, WCPF. 1985. Standar Methods for The Examination of Water and Wastewater Treatment. Edisi ke 16. American Public Health Association, American water Work Association and water Pollution Control Federation, Washington, D.C.

Babu, R. and M. Chauduri. 2005. "Home Water Treatment by Direct Filtration with Natural Coagulant". Journal of Water and Health. 3 (1) : 27-30.

Cohen, J.M. and S.A. Hannah. 1971. Coagulation and Flocculation. In : Water Quality and Treatment (a Handbook of Public water Supplies). Edisi ke 3. Mc Graw Hill. Inc. New York.

Culp, G. L., R. L. Culp and G. M. Wesner. 1986. Handbook of Public Water System.Van Norstrand Reinhold, NewYork.

Darmono. 1995. Logam dalam Sistem Biologi Makhluk Hidup. Edisi Pertama. Penerbit UI, Jakarta.

Duke, J.A. 1983. Handbook of Energy Crops. http://www.hortpurdue.edu/newcrop/d uke-energy/Vicia-faba.html. Diakses pada 4 Februari 2006.

Dwinarjati, D. 1995. Analisis Efisiensi Pengolahan Klorolignin pada Air Buangan Industri Pulp dengan Aplikasi Bioreaktor Cakram Biologi. Skripsi sarjana. Jurusan Teknik Lingkungan. Institut Teknologi Bandung.

Folkard, G. and J. Sutherland .2001. "The Use of Moringa oleifera Seed as a Natural Coagulant for Water and Wastewater Treatment". In Simposio Internacional Sobre Technologias De Apoio A Gestao De Recursos Hidricos.

Ghebremichael, K. A. 2004. "Moringa Seed and Pumice as Alternative Natural Materials for Drinking Water Treatment". http://www.lwr.kth.se/ publikationer/PDF_FILES/LWR_PHD _1013.pdf. Diakses pada 18 Juli 2006

Hauser, B.A .2002. Drinking Water Chemistry : a Laboratory Manual. Lewis Publishers, London.
Hidayat, S. 1999. Efektivitas Bioflokulan Biji Moringa oleifera dalam Proses Pengolahan Limbah cair Industri Pulp dan Kertas. Tesis. Departemen Biologi. Institut Teknologi Bandung.

Liew, A.G., M.J. M. M. Noor, and Y.M. Ng. 2004. "Turbid Water Clarification Using Extraction of Cowpea Seeds". KKU Engineering Journal. 31 (2) : 7382.

Ndabigengesere, A, and K. S. Narasiah .1998. "Use of Moringa oleifera Seed as a Primary Coagulant in Wastewater Treatment". Technology. 19 (8):789-800.

Nkhata, D .2001. "Moringa as an Alternative to Aluminium Sulphate". In : People and Systems for Water, Sanitation and Health. Proceeding of The $27^{\text {th }}$ WEDC Conferences, Zambia. pp 494-496.

Olphen, V.H .1977. An Introduction to Clay Colloid Chemistry. Edisi ke 2 John Willey \& Sons a Willey Interscience Publication, New York.

Poedjiadi, A .1994. Dasar- dasar Biokimia. UI Press, Jakarta.

Setyorini, D. 2002. Minimasi Limbah dalam Industri Pulp and Paper. http://www.terranet.or.id. Diakses pada 4 Februari 2006.

Singh, A .1976. Industrial Wastewater Handbook. MC Graw Hill Book. Inc, New York.

Sofiany, R .1999. Efektivitas Biji Moringa oleifera Lam dalam Memperbaiki Sifat Fisik Kimia Limbah cair Industri Penyamakan kulit di Sukaregang . Tesis. Departemen Biologi. Institut Teknologi Bandung.

Sutherland, J.P., G.K. Folkard, and W.D. Grant . 1990. "Natural Coagulants for Appropriate Water Treatment". A Novel Approach, Waterlines, 8 (4), 3032.

Waluyo, L. 2005. Mikrobiologi Lingkungan. Edisi pertama. UMM Press Malang. 
Wang, J and C. Chen. 2006. "Biosorption of Heavy Metals by Saccharomyces cerevisiae : A Review". Biotechnology Advances 24 : 427 - 451.

Wardhana, W. A .2004. Dampak Pencemaran Lingkungan. Penerbit ANDI, Yogyakarta. 